\title{
LEGALIZATION OF NURSE PRESCRIBING OF MEDICATION IN BRAZIL: HISTORY, TRENDS AND CHALLENGES
}

\author{
Claudia Santos Martiniano ${ }^{1}$, Paula Stefânia de Andrade ${ }^{2}$, Fernanda Carla Magalhães ${ }^{3}$, Fernanda Ferreira de \\ Souza ${ }^{4}$, Francisco de Sales Clementino ${ }^{5}$, Severina Alice da Costa Uchôa ${ }^{6}$
}

\begin{abstract}
${ }^{1}$ Ph.D. in Health Sciences. Professor Curso de Enfermagem, Universidade Estadual da Paraíba. Campina Grande, Paraíba, Brazil. E-mail: cmartiniano@ibest.com.br

${ }^{2}$ Nurse Estratégia Saúde da Família Gado Bravo. Gado Bravo, Paraíba, Brazil. E-mail: paula_andrade2186@hotmail.com

${ }^{3}$ M.Sc. in Nursing. Natal, Rio Grande do Norte, Brazil. E-mail: nandamag204@hotmail.com

${ }^{4}$ Occupational Nursing Specialist. Fellow Programa de Valorização da Atenção Básica. Juazeiro, Bahia, Brazil. E-mail: fernandaferreira-ffs@hotmail.com

${ }^{5}$ Ph.D. in nursing. Professor, Departamento de Enfermagem, Universidade Federal de Campina Grande. Campina Grande, Paraiba, Brazil. E-mail: fclementino67@yahoo.com.br

${ }^{6}$ Ph.D. in Public Health. Professor, Programa de Pós-Graduação em Ciências da Saúde, Universidade Federal do Rio Grande do Norte. Natal, Rio Grande do Norte, Brazil. E-mail: alicedacostauchoa@gmail.com
\end{abstract}

\begin{abstract}
This study aimed to identify the legal and normative contours of nurse prescribing of medications in Brazil, showing its history, trends and challenges. It is an exploratory study conducted through desk research of nursing law, the Health Ministry and the health sector norms to address this issue. The steps of a documentary study and the analysis of data contents were followed. The nursing discipline contributed to the legalization of prescription, but not to its legitimacy; this assignment in primary care is consolidated through protocols and legislation, although there is no clear strategy for monitoring by the Health Ministry; there is resistance in some norms within the health sector. We conclude that there is a trend of nurse prescribing of medication, which currently remains only as a legality, and the main challenge is to achieve legitimacy.
\end{abstract}

DESCRIPTORS: Nursing. Nursing legislation. Prescription medications.

\section{LEGALIZAÇÃO DA PRESCRIÇÃO DE MEDICAMENTOS PELO ENFERMEIRO NO BRASIL: HISTÓRIA, TENDÊNCIAS E DESAFIOS}

RESUMO: Objetivou-se identificar os contornos legais e normativos da prescrição de medicamentos por enfermeiros no Brasil apontando sua história, tendências e desafios. Estudo exploratório, realizado por meio de pesquisa documental da legislação da enfermagem, normatizações do Ministério da Saúde e do setor saúde que abordam a questão. Seguiram-se as etapas do estudo documental e a análise de conteúdo dos dados. A categoria da enfermagem contribuiu para a legalização da prescrição, porém não para a sua legitimação; na Atenção Básica, essa atribuição está consolidada por meio de protocolos e legislação, embora sem estratégia clara de acompanhamento pelo Ministério da Saúde; observa-se resistência em algumas normatizações dentro do setor saúde. Conclui-se que há tendência da prescrição de medicamento, por enfermeiros, permanecer apenas na legalidade e o principal desafio é alcançar a legitimidade.

DESCRITORES: Enfermagem. Legislação de enfermagem. Prescrição de medicamentos.

\section{LEGALIZACIÓN DE LA PRESCRIPCIÓN DE MEDICINAS POR EL ENFERMERO EN BRASIL: HISTORIA, TENDENCIAS Y DESAFÍOS}

\footnotetext{
RESUMEN: Se objetivó identificar contornos legales y normativos de la prescripción de medicinas por enfermeros en Brasil apuntando su historia, tendencias y desafíos. Es un estudio exploratorio, realizado por medio de investigación documental de la legislación de la enfermería, las normas del Ministerio de la Salud y del sector salud que abordan esta cuestión. Se siguieron etapas del estudio documental y el análisis de contenido de los datos. La categoría de enfermería contribuyó para legalización de la prescripción, pero no para su legitimación; en Atención Básica, esa atribución está consolidada por medio de protocolos y legislación, mismo sin estrategia clara de acompañamiento por el Ministerio de Salud; se observa resistencia en algunas normas dentro del sector salud. Se concluye que hay tendencia de la prescripción de medicinas, por enfermeros, permanecer solo en la legalidad y el principal desafío es alcanzar la legitimidad. DESCRIPTORES: Enfermería. Legislación de enfermería. Prescripción de medicinas.
} 


\section{INTRODUCTION}

This paper addresses the issue of nurse prescribing in its legal aspect. Although in some countries the practice extends to various levels of health care, ${ }^{1}$ this activity is restricted to primary health care in Brazil, more specifically to the Family Health Strategy (FHS).

The FHS was established in 1994 by the Brazilian Ministry of Health, known at the time as the Family Health Program (FHP) for redirecting health care that previously was based on technicalities/a hospital-centered model, based on the principles of the Unified Health System (Sistema Unificado de Saúde - SUS). It aimed to strengthen primary care through interdisciplinary practices developed by teams in the Family Basic Health Units (FBHU), which are responsible for a certain group of the population located within a territory. The nurse, as a member of the family health team, performs common activities, along with specific responsibilities, including: nursing consultation, diagnostic test requisitions and medication prescription, as established in the Ministry of Health Programs. ${ }^{2}$

Nurse prescribing is supported by Law $n$. 7498/1986 and Decree n. 94,406/1987, which regulate the profession; it is established as a nurse's activity as member of the healthcare team in public health programs, and is routinely approved by the health institution. However, this practice has been taking clearer shape in recent years, by publishing care protocols created by the Ministry of Health..$^{3-4}$

Although law establishes it, this practice has sparked intense debate by critics, especially physicians. ${ }^{5}$ Although there is legal support, and despite the judicial clashes, the discussion among professionals is still incipient, raising doubts. As a consequence, different practices related to this assignment are observed in health services. In addition, due to constant technological advancement, new laws are being implemented all the time in the health sector, including some referring to the prescription of medications and request for diagnostic tests by nurses, putting them constantly in evidence, since their limits do not seem clear to many health professionals, including nurses. Thus, the following questions are relevant to guide this study: what are the laws that guide nurse prescribing of medicine? What are the norms of the Ministry of Health that drive this assignment? What other health sector legislation may endorse or refute such actions?
Through the above, this article has the objective of identifying the legal and regulatory contours of nurse prescribing in Brazil, identifying its history, trends and challenges.

\section{METHOD}

Documentary research was conducted according to the type of exploratory study. This methodological feature applies to the proposed objectives, as the documents are sources of records that report events, values, and statements of a particular social group in a historical period, explaining intrinsic forms of social relations. ${ }^{6}$

The documents were selected from the preliminary assessment, using the dimensions proposed by Cellard: ${ }^{7}$ context analysis, the author/ authors, the authenticity and reliability of the text, the nature of the text, the key concepts and internal logic of the text. For data collection, a guide was used, according to the purpose of the research. The same guide was applied to each document analyzed, and the analysis was completed after successive readings of the data collected. ${ }^{8}$ The script included issues related to the implicit or explicit positioning regarding nurse prescribing, and their impact on the practice.

In this sense, specific nursing legislation was analyzed, such as the Professional Practice Law n. 7498/1986; ${ }^{3}$ Decree n. 94,406/1987, ${ }^{4}$ resolutions of the Conselho Federal de Enfermagem (COFEN): n. 271/2002; n. 317/2007; ${ }^{9}$ n. 272/2002; n. 358/200910 and n. 195/1997.11

The of Primary Care Ordinance n. 648/GM $2006^{12}$ and Ordinance n. 1625/GM 2007,, ${ }^{13}$ of the Health Ministry was included, available in http:// www.saude.gov.br/dab, along with Ordinance n. 2,488/GM $2011^{2}$ which granted consent for the current National Policy for Primary Care.

Finally, legislation implemented in the health sector was analyzed, highlighting: Law $\mathrm{n}$. $12,842 / 2013,{ }^{14}$ known as the Medical Practice Act Law; Resolutions of the Collegiate Board (Resoluções da Diretoria Colegiada -DRC) n. 44/201015 and n. 20/2011, ${ }^{16}$ related to the use of antimicrobials, and Ordinance 184/2011 ${ }^{17}$ which established the Popular Pharmacy Program in Brazil.

After this step, and with the research Corpus, data content analysis was initiated through distinct phases: pre-analysis, exploration of material or coding, processing of the inference and interpretation of the results. ${ }^{18}$ Based on the analyzed material, three categories were elected: legal paths 
taken by the nursing discipline for prescription of medications; nurse prescribing of medicine in primary health care; and, the legal implications for the health sector of nurse prescribing.

As this was documentary research, with public domain material available on the Internet, there was no need to submit the research project to an ethics committee.

\section{RESULTS AND DISCUSSION}

\section{The legal paths taken by the nursing discipline for prescription of medications}

The first legal instrument, which makes reference to nurse prescribing in Brazil is Federal Decree n. 20931 of January 11, 1932, which regulates and supervises, simultaneously, the practice of medicine, dentistry, veterinary medicine and pharmacy, midwifery and nursing professions. ${ }^{19}$

In this Decree, the nurse's role is described in Article 36 in conjunction with the midwife assignments. Article 37, item " $\mathrm{d}$ " describes what is forbidden to midwives: "prescribe medications, unless it is urgently demanded by the need to prevent or combat serious accidents that compromise the life of the mother, the fetus or newborn".${ }^{19}$ Note that it opens a basis for medication prescription by nurses, in this case, the midwife, although on an urgent basis. The decree is silent on nurse prescribing. In this legislation, only the physician and the dentist were considered prescribers, excluding the nurse and pharmacist.

In the 1950s, some questions surrounding technical orientation of the act arose; at that time, nurses began to emphasize the application of scientific criteria in their procedures, increasing reflections on the need to develop a specific body of knowledge that could give identity and autonomy to the profession. This period was characterized by efforts of the discipline to validate the nursing work process against the list of health sciences, in the social recognition of the profession, and give value to the act of caring. ${ }^{20}$

The Nursing Process (NP), established in 1985 by the World Health Organization from the theoretical, scientific and philosophical foundations of the profession, was reported as a method to achieve quality nursing care, and must be used by all nurses in their professional practice..$^{21}$ The operationalization of the NP in four stages (assessment, planning, implementation and evaluation) does not refer to prescription of medications as an integral part of the care.

The assignment of nurse prescribing of medicine was guaranteed in 1986 with the approval of Legislation n. 7498, which regulates the Professional Nursing Practice; in article 11, item II, letter " $c$ ", it describes nurse prescribing of medications in public health programs approved by the health institution, ${ }^{3}$ and Decree n. 94.406 of June 8, 1987, ratified this assignment. ${ }^{4}$ The limit for this assignment is within the public health programs created by the Ministry of Health.

Nurse prescribing of medicines emerges as an isolated practice in the nursing process, as consultation and prescription of nursing care, established in the same legislation, but not yet regulated. Only in the 1990s and mid-2000s were the normalizing legislations of nursing process introduced: Resolution n. 159/199322 of COFEN (Brazilian Federal council of nursing) regulating the nursing consultation, as well as Resolutions $n$. 272/2002 and n. 358/200910 COFEN, establishing the Nursing Care Operationalization (NCO) and implementation of the nursing process in public and private environments, where professional nursing care occurs.

Considering this aspect, it seems that there was a reversal of the norms that refers to the nursing process. For the nurse, there was an opportunity to prescribe medications, without a perceived necessity for doing so within her work processes. So, nurse prescribing has become an superfluous addition to the nursing consultation, standardization of care, or the nursing process as a whole, as shown in Figure 1, since the elements composing the nursing consultation and the systematization of nursing care do not include this activity.

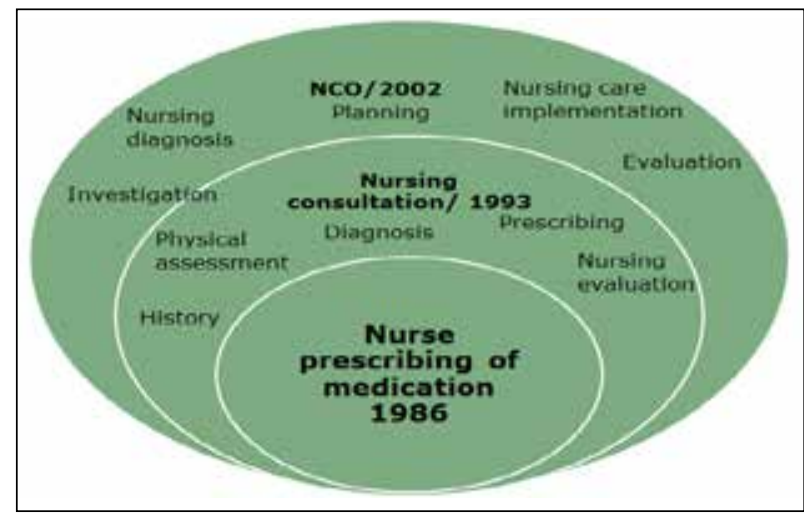

Figure 1 - Nurse prescribing of medication in the context of the nurse's work process 
Regarding diagnostic test requests, the COFEN - Resolution n. $195,{ }^{11}$ published about this subject in 1997, was based on the explanation that this attribution guarantees effective care without risk to the patient, even in the presence of prescription medications. This resolution indicates twelve programs and/or manual technical standards, published at the time by the Ministry of Health.

In 2002, COFEN published Resolution n. 271, which discussed nurse prescribing of diagnostic tests requested by nurses. Without expressing anything new, this resolution only ratified the law of professional practice. This resolution prevailed for only five years and was replaced in 2007, by Resolution n. 317, alleging that it was already provided in the professional nursing practice legislation. ${ }^{9}$ COFEN demonstrated the need to reaffirm the nurse prescribing of medication as a legal act. However, there is no movement within the discipline or it's representative organizations to legitimize this role in nursing, or to ensure the appropriate training to assume this responsibility.

Although the ministerial programs do not address the standardization of nursing care in health programs, nurse prescribing should be subsidized by NCO, a theoretical framework by which nursing practice is applied. ${ }^{23}$ The nursing consultation is inserted in this working process as an independent activity, aimed at the provision of conditions to improve the quality of life of users, family and community, through a contextualized and participatory approach. ${ }^{15}$

At this juncture, without the approach of $\mathrm{NCO}$, and if not inserted into the nursing consultation context, nurse prescribing tends to be a reproduction of the complaint-conduct model, ${ }^{25}$ whose professional-user relationship is guided by the restricted verbalization of symptoms by the user, that receives, in return, an immediate curative procedure.

Prescription of medicines was neither incorporated into the nursing consultation nor into the NCO, maybe, because the nursing discipline does not recognize this assignment as part of its responsibilities, which is to provide care. This attribution was strengthened only when a the nurse is a member of the primary health care team, justifying a restriction to this level of attention, unlike other countries where prescription of medicines by nurses occurs in other sectors of assistance. ${ }^{26}$

A concern that seems relevant, however, and which is not receiving proper attention at the local level, is that although the protocols published by Ministry of Health are based on global scientific evidence and express a national guideline, nurse prescribing must be legally established by the local manager, which has not occurred. The most common situation is the lack of a clear position on this nurse assignment by managers, ${ }^{27}$ that results in the absence of prescription regulation, by protocols or municipal ordinances. ${ }^{28}$

International experience has shown that legalizing nurse prescribing and the overcoming of resistance to their introduction in different countries can be achieved by the union of nurses and their agency representatives at the national level in supporting this practice. ${ }^{26}$ In countries such as the United Kingdom, with a long tradition of nurse prescribing, its expansion occurred from research supported by the government evaluating the acceptability, efficacy and safety of prescriptive nursing practice..$^{29-30}$

\section{Nurse prescribing of medications in primary health care}

As mentioned earlier, the privileged locus of prescription of medications and diagnostic tests is primary care, by means of FHS, whose basis is the multidisciplinary work based on interdisciplinarity, which in turn, requires an approach that challenges professional certainties and stimulates permanent horizontal communication between team members. ${ }^{31}$

In the FHS, all professionals have resized their professional roles, both as regards to individual action, and as a team member. Thus, the specific actions developed by nurses in the FHS, include among others: providing health care for individuals and families performing the comprehensive care actions at all stages of the life cycle: children, adolescents, adults and elderly in the level of their competencies; performing nursing consultation; requesting additional tests, prescribing/transcribing medications, according to protocols established by Ministry of Health Programs and the legal provisions of the profession; supervising and coordinating continuous education in health for training of Community Health Agents and nursing assistants; and, participating in the management of material resources from Basic Health Units. ${ }^{2}$

The development of care activities performed by nurses in the FHS, from health pro- 
motion and education activities, prevention and treatment of diseases, has enabled greater professional autonomy, providing significant social and political ascension of the profession. ${ }^{27}$ In this sense, it is emphasized that the work of nurses in the FHS enables the achievement of results consistent with their training, consolidating their role in the work process and demystifying social prestige marks and the lack of autonomy, found throughout professional history. ${ }^{32}$

In order to review the guidelines for organizing primary care performed in the FHS and Community Health Agents Program (CHAP), Decree n. 648/GM of March 28, 2006, was published approving the National Policy of Primary Care (NPPC). ${ }^{12}$ In its Annex I, which deals with the responsibilities of professionals from Family Health Teams, Oral Health and Community Health Agents, the Ordinance provides the following specific attributions of nurses: "I - Perform full assistance (health promotion and protection, disease prevention, diagnosis, treatment, rehabilitation and health maintenance) to individuals and families at FHS and, when indicated or necessary, at home and / or in other community spaces (schools, associations etc.), at all stages of human development: childhood, adolescence, adulthood and seniors; II - As protocols or other technical regulations established by the municipal manager or the Federal District, observing the legal provisions of the profession, performing nursing consultation, requesting additional tests and prescribing medications, $\left[\right.$...]" (our emphasis). ${ }^{12}$

The Brazilian Conselho Federal de Medicina (CFM) instigated a legal action, in February 2007, against this ordinance asking for its suspension, claiming that it allowed the practice of private medical acts by professionals who do not have a degree in medicine implying, therefore, risk of increased diseases and injury to public health. The Federal Regional Court of the First Region decided to suspend decree n. 648/2006 regarding "[...] the possibility of other professionals who are not legally qualified physicians to practice medicine, perform clinical diagnosis, prescribe medications, medical treatments and request examinations. ${ }^{33}$

Facing such an impasse, the Ministry of Health, seeking consensus with the representatives of the Councils of the categories involved, published Decree n. 1625 amending the Annex I of NPPC, related to the role of nurses of Family Health Teams, "I - Perform full care for individu- als and families at FHS and, when indicated or necessary, at home and/or in other community spaces. II - Perform nursing consultations, request additional tests and prescribe medications, observing the legal professional provisions and according to the protocols and other technical regulations established by the Ministry of Health, state or municipal authorities, or Federal District".$^{13}$

Establishing the NPPC, the Ministry of Health kept the legal norms provided by Law $n$. 7498/1986 of the Professional Practice in Nursing. The understanding of nursing discipline representatives is that prescribing medications and ordering diagnostic tests does not compromise the clinical diagnosis and autonomy of the medical professional. ${ }^{34}$

Thus, the Ministry of Health is keeping the prescription of medicines as an attribute of the professional nurse as part of primary health care in tuberculosis, leprosy, hypertension, diabetes, Attention to Children's Health, Integrated Management of Childhood Illness (IMCI), prenatal, sexually transmitted diseases protocols, among others. The publication of Decree n. 2488/2011, repealing Ordinance n. 648/2006, approves the NPPC, keeping the prescription of medicines and ordering of diagnostic tests, and continues to attribute to the nurse the function of referring users to other services when necessary. ${ }^{2}$ This situation may indicate a movement of continuity of the role that nurses has been assuming in primary care. Although this is just one of the assignments shared with other health professionals and not the most important in this model of care, it is the only one that has been questioned, especially by the medical professional.

In addition to the professional issue, there are no explicit motivations for nurses to assume the prescribing function in Brazil. However, the reaffirmation of this attribution through the protocols coincides with the expansion of health services supply and the difficulty with integrating physicians into the Family Health Strategy in a context of expense reduction for health. ${ }^{39}$ Given such a situation, the nursing activities provided them with more responsibility, in order to meet service demand. ${ }^{27}$

Ordinance GMn. 816, in 2005, established the National Steering Committee of Care Protocols, Therapeutic Guidelines and Technology Incorporation in Health, which among other responsibilities, sets criteria for evaluation, approval and 
incorporation of clinical and care protocols into the SUS. There are no nursing representatives in the composition of this committee. If, on one hand, the nurse is emerging with a prominent role in these protocols, on the other hand, it does not have guarantee participation in that committee. ${ }^{36}$

\section{Implications of health sector legislation on nurse prescribing of medications}

The health sector, in general, has been awarded with some legislation that focuses on the issue of nurse prescribing, placing the subject repeatedly at the center of debates.

Among these legislations, Law n. 12,842/2013, known as the Medical Practice Act, was processed more than a decade in the legislative scope in order to regulate general provisions on the practice of medicine, disregarding and infringing upon the legal bases of the different health professions, especially nursing. If approved, according to the original pretensions, it tends to jeopardize the prescriptive attribution of nurse, as in Article 4, paragraph I, establishing the formulation of diagnoses that classify diseases, and their therapeutic prescriptions, as a private activity of physicians. ${ }^{14}$

A class struggle by the professional monopoly was initiated by physicians and their representatives classes, lasting for years, diverging of what is meant by professional act, which is an action guided by regulatory rules of a profession in order to consolidate its professional identity ${ }^{37}$ The physicians obstinacy in accepting the full exercise of other professions was perceived, retaining the central role of the physician in health, as well as ignoring the evolution of the health care model, which aims to be interdisciplinary, and no longer physician-centered.

The outcome of that contest was the approval of the law, with vetoes in Article 4, among others, not guaranteeing to physicians, exclusively, the formulation of diagnosis and prescription. For nurses, the vetoes represent the maintenance of activities planned in the FHS protocols and the recognition of space for other healthcare categories. ${ }^{38}$

Another document that incurs on the prescriptive act of nurses is the Collegiate Board Resolution (RDC) n. 44 of 26 October 2010, which provides for the control of antimicrobial drugs. In this resolution, the Agência Nacional de Vigilância Sanitária (ANVISA) provides, in Articles 2 and 3 , that antimicrobial medications can only be provided by the prescription of an appropriately qualified professional, ${ }^{15}$ but it does not specify who is the prescribing professional.

In the existence of such uncertainty, the Nursing Councils required a position from ANVISA regarding who could prescribe antibiotics. In response, the agency published RDC. 20 of May 5,2011 , which amends the first resolution, set in article 4 , that legally qualified professionals should perform the prescription of antimicrobial covered in this resolution. ${ }^{16}$ Thus, nurse prescribing meets the provisions for the Law of Professional Practice, and enables the acquisition of antimicrobials.

Another Ordinance of the Ministry of Health, n. 184 of February 3, 2011, ${ }^{17}$ which provides for the Brazilian Popular Pharmacy Program (BPPP) (Programa Farmácia Popular do Brasil), in article 27 establishes that for commerce and dispensing of medications and/or related within the BPPP, pharmacies and drugstores should necessarily require a prescription, including the registration number of the physician in the Conselho Regional de Medicina (CRM), signature and stamp of the physician, contrary to the provisions of article 2 of RDC n. 20, which states that private pharmacies and drugstores, as well as public, such as the units belonging to BPPP must dispense medications by retaining a bookkeeping receipt in accordance with this resolution. ${ }^{16}$

Thus, based on these legal provisions, there is an inconsistency between the documents of ANVISA and those which regulate the BPPP, allowing a divergent and antagonistic ministerial statement, as well as a dichotomy within professional nursing legislation as regards the nurse as a professional legally enabled to prescribe medication within public health programs; however, the same prescription is not accepted at pharmacies which, in turn, are also regulated by the Ministry of Health.

In this regard, the full implementation of the nurse's role is denied, since nurses do not have enough autonomy to ensure full care for the user, according to some documents of the Ministry of Health and infringing legislation, leading to the instability of the attribution of nurse prescribing within the Ministry of Health.

\section{FINAL CONSIDERATIONS: TRENDS AND CHALLENGES}

The prescription of medications by nurses is legally secured through the regulation of the profession, in the Law of Professional Practice of Nursing. However, 28 years after creation of this 
law, it remains under discussions, challenging the legality and effectiveness of this attribution, contrary to the legal basis of the profession, as well as ministerial documents, which also recognize this role of the nurse prescriber.

The trend is that the issuance of prescription medications by nurses still meets with resistance, especially from physicians, who do not understand that prescription medications historically belonged to the core medical activities, but are now recognized as part of the activities within many health professions, composing, a common area between the professions of mutual support in performing their activities.

These discussions will continue until the historical medical focus is overcome, allowing the recognition of this professional category, so that all professions achieve their place in this new health organization model, in which interdisciplinarity is the working method.

On the other hand, there is a lack of commitment from nurses with regard to the fight for legitimacy of this attribution. There is a lack of knowledge about the legislation that guides the profession, a gap that exists within the educational process, and an incipient debate on health services on this topic, given the non-standardization of health care by staff, based on protocols established by the Ministry of Health.

Thus, it is mandatory to mobilize the discipline of nurses in order to have the recognition of their prescriptive authority, assured since its regulation, which has been regarded as part of the scope of tools for professional autonomy.

A major challenge is the achievement of new relationships of nurses with other team members, users and health services managers. Positions of submission assumed by nurses do not favor a climate of trust and respect needed to develop the responsibility of prescribing medication even when confronted with the prerogative of teamwork in primary care.

Another challenge is to eliminate the polarization that the prescription of medications assumes in the routine of nurses, in which some refuse to prescribe while others assume such an assignment as an isolated function within the nursing work process. Although medications to be prescribed are within pre-defined protocols, the nurse must associate the standardization of nursing care as scientific support to subsidize the nursing consultation.

\section{REFERENCES}

1. Van Ruth LM, Mistiaen P, Francke AL. Effects of nurse prescribing of medication: a systematic review. J Internet Healthcare Admin [online]. 2008 [acesso 2011 Mai 21]; 5(2). Disponível em: http:// www.ispub.com/journal/the-internet-journal-ofhealthcareadministration/volume-5-number-2/ effects-of-nurse-prescribing-of-medication-asystematic-review.html

2. Ministério da Saúde (BR). Portaria n. 2.488 de 21 de outubro de 2011: aprova a Política Nacional de Atenção Básica, estabelecendo a revisão de diretrizes e normas para a organização da Atenção Básica, para a Estratégia Saúde da Família (ESF) e o Programa de Agentes Comunitários de Saúde (PACS) [online]. Brasília (DF): MS; 2011. [acesso 2014 Out 24]. Disponível em: http://bvsms.saude.gov.br/bvs/ saudelegis/gm/2011/prt2488_21_10_2011.html.

3. Brasil. Lei n. 7.498, de 25 de junho de 1986: dispõe sobre a regulamentação do exercício da enfermagem e dá outras providências. Diário Oficial da União. 1986 jun. 26; Seção 1. p. 1.

4. Brasil. Decreto-Lei n. 94.406, de 08 de Junho de 1987. Regulamenta a Lei n. 7.498 , de 25 de Junho de 1986, que dispõe sobre o exercício da enfermagem [online]. Diário Oficial [da] União. 1987 jun. 9 [acesso 2011 mai 21]. Disponível em: http:/ /www. portalcofen.gov.br/Site/2007/ default.asp $\% 20$ acesso $\% 20 \mathrm{em} \% 2025 / 05 / 2010$.

5. Borges IAL. Consulta de enfermagem, prescrição de medicamentos e solicitação de exames por enfermeiros na atenção básica à saúde. Enferm Foco; 2010, 1(1):5-8.

6. Richardson RJ. Pesquisa social: métodos e técnicas. $2^{a}$ ed. São Paulo (SP): Atlas; 1989.

7. Cellard A. A análise documental. In: Poupart J, Deslauries JP, Groulx LH, Laperrière A, Mayer $R$, Pires AP. A pesquisa qualitativa: enfoques epistemológicos e metodológicos. Petrópolis (RJ): Vozes; 2008.

8. Lima TCS, Mioto RCT. Procedimentos metodológicos na construção do conhecimento científico: a pesquisa bibliográfica. Rev Katálysis. 2007; 10 (Esp):37-45.

9. Brasil. Conselho Federal de Enfermagem. Resolução n. 317/2007: revoga a Resolução COFEN n. 271/2002 [online]. COFEN; 2007 [acesso 2011 mai 21]. Disponível em: http:/ / site.portalcofen.gov.br/node/4351

10. Brasil. Conselho Federal de Enfermagem. Resolução n. 358/2009: dispõe sobre a Sistematização da Assistência de Enfermagem e a implementação do Processo de Enfermagem em ambientes, públicos ou privados, em que ocorre o cuidado profissional de Enfermagem, e dá outras providências 
[online]. COFEN; 2009 [acesso 2011 Mai 21]. Disponível em: http://www.cofen.gov.br/resoluocofen-3582009_4384.html

11. Brasil. Conselho Federal de Enfermagem. Resolução n. 195/1997: dispõe sobre a solicitação de exames de rotina e complementares por Enfermeiro [online]. COFEN; 1997 [acesso 2011 Mai 21]. Disponível em: http:/ / www.cofen.gov.br/resoluocofen-1951997_4252.html

12. Ministério da Saúde (BR). Portaria n. 648/GM/2006: aprova a Política Nacional de Atenção Básica, estabelecendo a revisão de diretrizes e normas para a organização da Atenção Básica para o Programa Saúde da Família (PSF) e o Programa Agentes Comunitários de Saúde (PACS) [online]. Brasília (DF): MS; 2006 [acesso 2011 Mai 15]. Disponível em: http://bvsms.saude. gov.br/bvs/publicacoes/prtGM648_20060328.pdf

13. Ministério da Saúde (BR). Portaria n. 1.625 de julho de 2007. Altera as atribuições dos profissionais das Equipes de Saúde da Família - ESF dispostas na Política Nacional de Atenção Básica [online]. Brasília (DF): MS; 2007 [acesso 2012 Out 24]. Disponível em: http://bvsms.saude.gov.br/bvs/saudelegis/ gm/2007/prt1625_10_07_2007.html

14. Brasil. Lei n. 12.842, de 10 de julho de 2013. Dispõe sobre o exercício da medicina. Diário Oficial da União, 11 jun 2013.

15. Brasil. Resolução da Diretoria Colegiada - RDC n. 44, de 26 de outubro de 2010. Diário Oficial [da] União. Brasília, DF. 2010 out 28; Seção 1.

16. Brasil. Resolução da Diretoria Colegiada - RDC n. 20 de 05 de maio de 2011. Diário Oficial [da] União. Brasília, DF. 2011 mai 9; Seção 1. p. 40.

17. Ministério da Saúde (BR). Portaria n. 184 de 3 de fevereiro de 2011: dispõe sobre o Programa Farmácia Popular do Brasil [online]. Brasília (DF): MS; 2011 [acesso 2011 Mai 21]. Disponível em: http:// bvsms.saude.gov.br/bvs/saudelegis/gm/2011/ prt0184_03_02_2011.html

18. Bardin L. Análise de conteúdo. Lisboa (PT): Edições 70, 2009.

19. Brasil. Decreto Federal n. 20.931 de 11 de janeiro de 1932: regula e fiscaliza o exercício da medicina, da odontologia, da medicina veterinária e das profissões de farmacêutico, parteira e enfermeira, no Brasil, e estabelece penas [online]. Rio de Janeiro: 11 Jan 1932 [acesso 2011 Mai 3]. Disponível em: http://www.jusbrasil.com.br/legislacao/116714/ decreto-20931-32

20. Souza MF. Teorias de enfermagem: importância para a profissão. Acta Paul Enferm. 1988; 1(3):63-35.

21. Barra DCC, Sasso GTMD. Processo de enfermagem conforme a classificação internacional para as práticas de enfermagem: uma revisão integrativa.
Texto Contexto Enferm [online]. 2012 Jun [acesso 2014 Jul 15]; 21(2):440-7. Disponível em: http:/ / www. scielo.br/scielo.php?script=sci_arttext\&pid=S010407072012000200024\&lng=pt

22. Brasil. Conselho Federal de Enfermagem. Resolução n. 159/1993: dispõe sobre a consulta de Enfermagem [online]. COFEN; 1993 [acesso 2011 mai 21]. Disponível em: http:/ / www.cofen.gov.br/resoluocofen-1591993_4241.html

23. Tannure MC, Pinheiro AM. SAE: sistematização da assistência de enfermagem: guia prático. Rio de Janeiro (RJ): Guanabara Koogan; 2011.

24. Machado MMT, Leitão GCM, Holanda FUX. O conceito de ação comunicativa: uma contribuição para a consulta de enfermagem. Rev Latino-Am Enfermagem. 2005; 13(5):723-8.

25. Mendes-Gonçalves RB. Tecnologia e organização social das práticas de saúde. São Paulo (SP): Hucitec; 1994.

26. Martiniano CS, Coêlho AA, Latter S, Uchôa SAC. Medication prescription by nurses and the case of the Brazil: what can we learn from international research? Int J Nurs Stud. 2014, 51(8):1071-3.

27. Ximenes Neto FRG, Costa FAM, Chagas MIO, Cunha ICKO. Olhares do enfermeiro acerca de seu processo de trabalho na prescrição de medicamentos na Estratégia Saúde da Família. Rev Bras Enferm. 2007; 60(2):133-40.

28. Vasconcelos RB, Araújo JL. A prescrição de medicamentos pelos enfermeiros na Estratégia Saúde da Família. Cogitare Enferm. 2013; 18(4):743-50.

29. Latter S, Maben J, Myall M, Young A. Evaluating the clinical appropriateness of nurses' prescribing practice: method development and findings from an expert panel analysis. Qual Saf Health Care. 2007; 16(6):415-21.

30. Latter S, Maben J, Myall M, Young A. Evaluating nurse independent prescribers' prescribing consultations: an observation study of practice in England. J Res Nurs. 2007; 12(1):7-26.

31. Araújo MFS, Oliveira FMC. A atuação do enfermeiro na Equipe de Saúde da Família e a satisfação profissional. Rev Eletr Cienc Sociais [online]. 2009 [acesso 2011 Mai 21]; (14):3-14. Disponível em: http://www.cchla.ufpb.br/ caos/n14/DOSSIE\% 20SA \% C3\% 9 A DE_ TEXTO $\% 20$ I_ATUA $\%$ C3\%87\%C3\%83O $\% 20 \mathrm{DO} \% 20$ ENFERMEIRO.pdf

32. Araújo MFS. O enfermeiro no Programa Saúde da Família: prática profissional e construção de identidade. Rev Conceitos. 2005; (12):39-43.

33. Brasil. Tribunal Regional Federal - $1^{\text {a }}$ Região. Agravo de Instrumento N. 2007.01.00.000126-2/ DF [Internet]. Brasília (DF): TRF; 2010 [acesso 2010 Set 
20]. Disponível em: http://jornal.crmmg.org.br/ v2/2008/16/ma07.php

34. Conselho Federal de Enfermagem. Mensagem da Presidente [online]. Publicada em março de 2007. [acesso 2010 Maio 20]. Disponível em: http://www.portalcofen.gov.br/Site/2007/print. asp?articleID $=7136$

35. Oguisso T, Freitas GF. Enfermeiros prescrevendo medicamentos: possibilidades e perspectivas. Rev Bras Enferm [online]. 2007 [acesso 25 Ago 2012]; 60 (2):141-4. Disponível em: http:// www.scielo.br/scielo.php? pid=S0034$71672007000200003 \&$ script $=$ sci_arttext

36. Ministério da Saúde (BR). Portaria n. 816 de 31 de março de 2005: constitui o Comitê Gestor
Nacional de Protocolos de Assistência, Diretrizes Terapêuticas e Incorporação Tecnológica em Saúde, e dá outras providências [online]. Brasília (DF): MS; 2005 [acesso 2011 Mai 21]. Disponível em: http:// bvsms.saude.gov.br/bvs/saudelegis/gm/2005/ prt0816_31_05_2005.html

37. Guimarães RGM, Rego S. O debate sobre a regulamentação do ato médico no Brasil. Ciênc Saúde Coletiva. 2005; 10(Supl):7-17.

38. Conselho Federal de Enfermagem. COFEN defende manutenção do veto presidencial ao Ato Médico [online]. 2013. [acesso 18 Jul 2013]. Disponível em: http://novo.portalcofen.gov.br/cofendefende-manutencao-do-veto-presidencial-ao-atomedico_20426.html 